\title{
PENGARUH PERUBAHAN HIPERPLASIA SEL GOBLET SELAMA 28 HARI PAPARAN ASAP ROKOK DENGAN PEMBERIAN ANTIOKSIDAN SUPEROXIDE DISMUTASE
}

\author{
Rivan Virlando Suryadinata ${ }^{1}$, Bambang Wirjatmadi ${ }^{2}$, Merryana Adriani ${ }^{2}$ \\ ${ }^{1}$ Fakultas Kedokteran, Universitas Surabaya \\ ${ }^{2}$ Departemen Gizi Kesehatan, Fakultas Kesehatan Masyarakat, Universitas Airlangga \\ Alamat Korespondensi: \\ Rivan Virlando Suryadinata \\ Email: rivan.virlando.suryadinata@gmail.com
}

\begin{abstract}
The number of Indonesian smokers in 2013 has reached 36.3\% and continues to increase each year. This will directly affect the increase in passive smokers in Indonesia. Harmful free radicals from cigarette smoke inhaled can lead to irritation of the bronchial airways. Irritation of the airways characterized by mucus hypersecretion induced goblet cell hyperplasia of the bronchi. Giving antioxidants superoxide dismutase melon extract with a combination of gliadin (SOD-gliadin) reduces radical that goblet cell hyperplasia in the bronchial airways can be reduced. This study aims to determine the effectiveness of the SOD-gliadin to the decrease of goblet cell hyperplasia of the bronchi. Giving SOD-gliadin carried out for 28 days with exposure to smoke two cigarettes per day using 5 groups: negative control, positive control and 3 treatment groups with different doses (2,25 IU; 4,5 IU; 9 IU). Observation of goblet cell hyperplasia performed on histological preparations with a longitudinal section with four visual field. With the effects of the antioxidant superoxide dismutase melon extract on percentage of goblet cell hyperplasia (ANOVA, $p=0396$ ). It can be concluded supplementation with SOD-gliadin not influence the percentage of goblet cell hyperplasia.
\end{abstract}

Keywords: goblet cell, superoxide dismutase, antioxidants, cigarette, free radical

\begin{abstract}
ABSTRAK
Jumlah perokok di Indonesia pada tahun 2013 telah mencapai 36,3\% dan terus meningkat setiap tahunnya. Hal ini secara langsung akan memberikan dampak peningkatan perokok pasif di Indonesia. Radikal bebas berbahaya dari asap rokok yang terhirup dapat mengakibatkan iritasi pada saluran napas bronkus. Iritasi saluran napas bronkus ditandai dengan hipersekresi mukus yang disebabkan adanya hiperplasia sel goblet pada bronkus. Pemberian Antioksidan Superoxide dismutase dari ekstrak melon dengan kombinasi gliadin (SOD-gliadin) dapat mengurangi radikal sehingga hiperplasia sel goblet pada saluran napas bronkus dapat berkurang. Penelitian ini bertujuan untuk mengetahui efektivitas SODgliadin terhadap penurunan hiperplasia sel goblet pada bronkus. Pemberian SOD-gliadin dilakukan selama 28 hari dengan paparan asap rokok 2 batang per hari dengan menggunakan 5 kelompok yaitu kontrol negatif, kontrol positif dan 3 kelompok perlakuan dengan dosis yang berbeda (2,25 IU, 4,5 IU, dan 9 IU per hari). Pengamatan hiperplasia sel goblet dilakukan pada preparat histologi dengan potongan membujur dengan 4 lapang pandang. Hasil penelitian pengaruh antioksidan superoxide dismutase dari ekstrak melon terhadap persentase hiperplasia sel goblet (ANOVA, $p=0.396$ ). Sehingga dapat disimpulkan pemberian suplemen SOD-gliadin belum memberikan pengaruh persentase hiperplasia sel goblet.
\end{abstract}

Kata kunci: sel goblet, superoxide dismutase, antioksidan, rokok, radikal bebas 


\section{PENDAHULUAN}

Rokok merupakan salah satu masalah utama kesehatan di Indonesia. Meningkatnya jumlah perokok aktif setiap tahunnya secara otomatis diimbangi dengan peningkatan perokok pasif. Pada tahun 2007 jumlah perokok pasif di Indonesia telah mencapai $40,5 \%$, dimana $59,1 \%$ dari jumlah perokok pasif adalah anak balita (Kementerian Kesehatan RI, 2014). Pada anak usia sekolah antara 13-15 tahun paparan asap rokok terbanyak terjadi di luar rumah yaitu sekitar $78,1 \%$ dan di dalam rumah berkisar $68,8 \%$. Sedangkan pada tahun 2011 meningkat menjadi $85,4 \%$ terpapar asap rokok di luar rumah dan 78,4\% terpapar asap rokok di dalam rumah (World Health Organization, 2011).

Perokok juga menimbulkan kerugian secara fisik dan ekonomi. Di Indonesia kerugian ekonomi total penduduk dalam setahun akibat rokok telah mencapai 338,75 trilliun atau enam kali dari pendapatan cukai rokok pemerintah yang hanya 53,9 trilliun. Secara fisik, merokok cenderung menyebabkan kemerosotan daya kerja penduduk yang berakibat menurunnya produktivitas perusahaan dan produktivitas nasional, diperkirakan tiap batang rokok menyebabkan hilangnya waktu produktif kerja sebanyak 10 menit. Secara makro terdapat kehilangan tahun produktif (DALYs Loss/ Disability Adjusted Life Years Loss) sebesar 13.935,68 (7.575,22 untuk laki-laki dan 6.360,46 untuk perempuan) atau 25,5\% dari total DALYs Loss dalam tahun yang sama sekitar 51.250 DALYs Loss (Direktorat Jenderal PP dan PL, 2011).

Pada bidang kesehatan, biaya pengobatan yang dikeluarkan masyarakat akibat merokok selama setahun berkisar 15,44 trilliun. Selain itu, asap rokok dapat memicu lebih dari 25 macam penyakit, mulai dari penyakit saluran pernapasan, kanker paru-paru, penyakit melemahkan potensi sumber daya manusia (Direktorat Jenderal PP dan PL, 2011).
Kandungan bahan kimia berbahaya pada asap rokok akibat pembakaran yang tidak sempurna akan membentuk radikal bebas. Radikal bebas yang terbentuk dari pembakaran rokok akan berikatan dengan oksigen reaktif yang menghasilkan Reactive Oxygen Species atau sering disebut dengan ROS. Radikal bebas yang masuk ke dalam saluran napas dapat menyebabkan gangguan mekanisme pertahanan antioksidan tubuh sehingga mengakibatkan kerusakan sel (Angelis et al, 2014).

Radikal bebas pertama kali terbentuk melalui sistem transport elektron mitokondria. Dalam menghasilkan energi, mitokondria menggunakan 4 elektron pada reaksi berantai. Beberapa elektron yang melepaskan diri dari reaksi mitokondria berikatan langsung dengan oksigen dan membentuk anion superoxide. Oksigen sebenarnya adalah suatu bi-radikal karena memiliki dua elektron yang tidak berpasangan namun karena adanya spin paralel maka kedua elektron tidak dapat membentuk ikatan yang stabil dan berada di orbital yang terpisah. Agar oksigen dapat menerima elektron maka spin salah satu elektron pada oksigen atau spin pada pasangannya harus berubah dan proses ini membutuhkan waktu yang lebih panjang karena berlangsung dalam beberapa tahap (Sisein, 2014).

Reduksi elektron pada molekul oksigen merupakan cara untuk membentuk ikatan stabil. Molekul oksigen dapat menerima 4 elektron agar tereduksi menjadi 2 molekul $\mathrm{H}_{2} 0$, Namun pada tahap pertama reduksi elektron membutuhkan zat pereduksi yang kuat. Enzim yang dapat mengkatalisis reduksi oksigen, misalnya sitokrom oksidase karena memiliki mekanisme untuk menyebabkan retriksi spin dan kebutuhan energi untuk transfer elektron pertama (Augusto and Miyamoto, 2011).

Secara fisiologis radikal bebas yang masuk ke dalam saluran napas bronkus akan didetoksifikasi oleh sel makrofag, neutrofil, dan eosinofil. Namun, peningkatan jumlah radikal bebas yang berlebih dalam 
saluran napas akan memicu pergerakan sel makrofag, neutrofil, dan eosinofil yang dapat menimbulkan reaksi inflamasi. Radikal bebas utama yang berperan terjadinya reaksi inflamasi adalah radikal superoxide dikarenakan memiliki waktu paruh yang lebih panjang sehingga jumlah sel target yang terkena menjadi lebih besar sehingga dapat menimbulkan kerusakan dan kematian sel yang lebih banyak (Gutowski and Kowalczyk, 2013).

Pada orang sehat, terdapat mekanisme pertahanan saluran napas yang berfungsi membatasi masuknya zat melalui permukaan saluran napas serta menghilangkan partikelpartikel yang diendapkan di sepanjang saluran napas dan alveoli paru melalui reflek batuk, mukosiliar dan imunologi. Pada cabang bronkus terdapat sel silia yang berfungsi sebagai penyaring partikelpartikel udara dengan ukuran partikel sekitar 0,5-5 $\mu \mathrm{m}$, namun pada perokok, sel silia mengalami kerusakan sehingga mekanisme pertahanan menjadi terganggu yang berakibat terjadinya proses inflamasi dan penyempitan saluran napas. Saluran napas dapat dikatakan mengalami hambatan atau penyempitan bila terjadi pengurangan luas penampang saluran napas lebih dari $30 \%$ dari luas penampang saluran napas normal (Vlahos and Bozinovski, 2014).

Paparan asap Rokok dapat menimbulkan respon inflamasi di saluran napas perifer dan parenkim paru. Radikal bebas pada asap rokok yang masuk ke dalam saluran napas secara langsung dapat mengganggu mekanisme pertahanan antioksidan tubuh serta dapat mengakibatkan terjadinya kerusakan atau oksidasi pada lipid, protein dan DNA pada sel. Radikal bebas yang masuk akan di detoksifikasi oleh sel makrofag, neutrofil, eosinofil dan sel epitel. Hasil dari detoksifikasi radikal bebas oleh sistem pertahanan tubuh berupa Reactive Oxygen Species (ROS) (Angelis et al., 2014).

Inflamasi yang terjadi pada saluran napas akan membuat kerusakan sel-sel silia bronkus, yang secara fisiologis berfungsi sebagai pelindung paru melalui penyaringan berbagai partikel yang terhirup ke dalam saluran napas. Kerusakan sel-sel silia pada saluran napas akan mengakibatkan terjadinya hipersekresi mukus sehingga menyebabkan penyempitan saluran napas (Russi et al, 2013).

Proses inflamasi dan perubahan fibrotik yang disebabkan oleh asap rokok dapat ditemukan pada bronkiolus dan bronkiolus terminalis. Terjadinya inflamasi pada bronkiolus, tidak selalu menunjukkan gejala sesak dan hipersekresi mukus. Secara histologi membran bronkiolus pada saluran pernapasan mengandung sel infiltrat berupa limfosit dan histiosit hingga jaringan peribronchiolar, sedangkan pada alveolar paru terdapat sel makrofag sebagai sistem pertahanan. Namun letak bronchiolus dengan alveolar paru yang dekat, membuat makrofag juga dapat ditemukan pada bronkiolus (Allen, 2010).

Asap rokok pada saluran napas akan secara langsung mendorong pergerakan makrofag, limfosit, dan neutrofil. Partikel dan asap rokok yang masuk akan mengaktifkan mediator inflamasi dan faktor kemotatik, yaitu tumor necrosis factor-a (TNF-a), interleukin IL-6, interleukin IL-8, monocyte chemotactic peptide (MCP)-1, leukotriene LTB4 dan reactive oxygen species, and sekresi enzim proteolytic (khususnya MMP-9 dan MMP-12). Faktor kemotatik terutama interleukin IL-8 dan leukotriene LTB4 akan mempengaruhi pergerakan neutrofil menuju ke saluran pernapasan, sehingga mempengaruhi pengeluaran produksi dari kelenjar lendir submukosa dan perkembangan sel goblet yang berlebihan (Angelis et al., 2014).

Neutrofil akan mensekresi protease serin, termasuk NE (neutrofil elastase), cathepsin G dan proteinase-3, serta MMP-8 dan MMP-9, yang berkontribusi terhadap kerusakan paru-paru. Neutrofil bermigrasi ke saluran pernapasan bawah akibat rangsangan dari faktor kemotaktik 
neutrofil, yang meliputi IL-8. kelangsungan hidup neutrofil pada saluran pernapasan dipengaruhi oleh sitokin, seperti GM-CSF (granulocyte/makrofag colony-stimulating factor) dan G-CSF (granulocyte colonystimulating factor). Selain itu, peningkatan jumlah sel $\mathrm{T}$ juga terlihat pada perokok. Sel T meningkatkan kadar CD4 + dan CD8 + di dinding saluran napas. CD 8 yang disekresikan oleh sel $\mathrm{T}$ yang penting untuk resolusi infeksi virus, namun bila berlebihan dapat menimbulkan kerusakan akibat inflamasi paru-paru dan penurunan fungsi paru-paru. Persentase jumlah mediator inflamasi yang terdiri dari neutrofil, makrofag, sel CD4, CD8 + sel, sel-B dan limfosit juga menentukan banyaknya peradangan yang terbentuk pada saluran napas (Vlahos and Bozinovski, 2014).

Sistem mukosiliar pada saluran napas terdiri dari sel goblet dan sel silia yang berupa silia atau rambut (Boucherat et al., 2013). Pada saluran napas normal, mukus diproduksi dan diekskresikan oleh sel mukosa atau disebut juga sel goblet. Kelenjar sub mukosa pada saluran napas atas juga berfungsi sebagai penghasil mukus. Mukus tersusun oleh air, ion, lipid, protein dan glikoprotein kompleks yang disebut mucin. Mukus berfungsi untuk melapisi lumen saluran napas dan pada kondisi normal juga dapat melindungi epitel saluran napas terhadap alergen yang dihirup, pembersihan benda asing dan agen infeksi yang masuk ke saluran napas (Hayashi, 2012).

Sumber utama sekresi lendir pada saluran pernapasan adalah sel goblet pada epitel permukaan dan sel mukosa pada kelenjar submukosa. Pada paru normal, sel goblet terletak paling banyak pada saluran napas bagian atas seperti bronkus, semakin menuju ke bawah pada bagian bronkiolus jumlah sel goblet semakin menurun, sedangkan kelenjar sub mukosa hanya ada pada saluran napas atas dan tidak terdapat pada saluran bronkiolus. Dalam penyakit saluran pernapasan, terjadi pembesaran kelenjar sub mukosa (hipertrofi) dan peningkatan jumlah sel goblet (hiperplasia), sehingga terjadi penebalan saluran napas. Peningkatan rasio jumlah sel goblet dibanding sel silia dan peningkatan densitas sel goblet pada bronkiolus terminalis, menunjukan terjadinya hiperplasi sel goblet dan memicu kerusakan clearance mukus melalui mekanisme mukosiliar atau reaksi batuk (Silva and Bercik, 2012).

Hiperplasia sel goblet adalah peningkatan jumlah sel goblet pada epitel saluran napas (Hayashi, 2012). Inflamasi saluran napas akibat paparan zat alergen pada saluran napas yang dapat memicu terjadinya hipersekresi mukus dan merupakan konsekuensi dari peningkatan jumlah sel goblet. Banyaknya jumlah sel goblet yang dihasilkan mencerminkan hiperplasia (pembelahan sel) atau metaplasia (diferensiasi sel progenitor atau trans differentiation jalan napas epitel sel). Perubahan patologis ini, akan menyebabkan penyempitan saluran napas dan obstruksi saluran napas (Silva and Bercik, 2012).

Radikal superoxide dapat dinetralisir secara alami oleh antioksidan superoxide dismutase dalam tubuh. Namun banyaknya radikal bebas yang masuk ke dalam saluran napas akibat paparan asap rokok akan menyebabkan terjadinya ketidakseimbangan jumlah radikal bebas dengan antioksidan dalam tubuh sehingga diperlukan tambahan asupan antioksidan. (Kahnamoei et al, 2014).

Antioksidan enzimatik berupa antioksidan superoxide dismutase memiliki efektivitas yang lebih baik dibanding antioksidan non enzimatik seperti vitamin, caroteoid dan thiol. Pada manusia, binatang dan tumbuhan secara alami dapat menghasilkan antioksidan enzimatik secara alami. Namun, perbandingan kandungan Superoxide Dismutase pada tumbuhan lebih efektif dibandingkan dari manusia dan hewan, sehingga kandungan Superoxide Dismutase pada tumbuhan sering digunakan sebagai suplemen antioksidan (Romao, 2015). 
Pada tanaman banyak mengandung antioksidan superoxide dismutse dikarenakan banyaknya komponen penghasil Reactive Oxygen Species seperti pada kloroplast, mitokondria, membran plasma, apoplast, retikulum endoplasma dan dinding sel. Hal ini menjadikan tanaman memiliki banyak kandungan antioksidan enzimatik untuk menetralisir seperti superoxide dismutase (SOD), ascorbate peroxidase (APX), catalase (CAT), glutathione peroxidase (GPX), and peroxiredoxin (PrxR) (Filiz and Tombuloglu, 2015).

Kandungan antioksidan yang tinggi pada tumbuhan memberikan potensi pengembangan produk nutrisi sebagai antioksidan enzimatik dan salah satu antioksidan yang dikembangkan adalah superoxide dismutase. Sifat-sifat antioksidan ini dapat diperoleh melalui ekstrak melon (Cucumis Melo LC) sebagai bahan aktif dan biopolimer gliadin gandum (Triticum vulgare) sebagai pembawanya (Vouldoukis et al, 2014).

Ekstrak Melon (Cucumis Melo LC) memiliki kandungan SOD yang tinggi yaitu $100 \mathrm{U} / \mathrm{mg}$ dibanding antioksidan enzimatik lainnya seperti catalase (CAT) sekitar $10 \mathrm{U} / \mathrm{mg}$ dan glutathione peroxidase (GPX) sekitar $1 \mathrm{U} / \mathrm{mg}$. Oleh karena itu Ektrak Melon (Cucumis Melo LC) dengan Superoxide Dismutase telah dikembangkan sebagai suplemen makanan. Namun kandungan antioksidan pada buah melon sangat dipengaruhi oleh cara penanaman, pengolahan serta konsumsinya sehingga pembuatan suplemen dari ektrak melon merupakan pilihan utama agar kandungan antioksidan superoxide dismutase menjadi stabil (Nivedhini et al, 2014). Selain itu, SOD dari ekstrak melon memiliki sifat $\mathrm{pH}$ rendah dan aktivitas proteolitik tinggi dalam saluran pencernaan, sehingga enzim-enzim pada saluran pencernaan akan mengurangi efektifitas SOD (Superoxide Dismutase) per oral. Untuk mengatasi hal ini, Ekstrak melon per oral diberikan pelapis atau pembawa berupa gliadin gandum (Triticum vulgare) yang melindungi degradasi asam lambung dan membantu penyerapan pada usus besar, sedangkan hambatan penyerapan pada usus kecil tidak secara langsung terjadi, hal ini disebabkan karena SOD per oral merupakan protein dengan berat molekul yang besar. (Romao, 2015).

Sebagai percobaan untuk mengetahui manfaat efektivitas SOD dari ekstrak Cucumis melo terhadap penurunan hiperplasia sel goblet pada saluran napas dapat diketahui dengan melihat preparat histologi bronkus. Pada penelitian ini menggunakan hewan coba tikus jantan galur wistar (Rattus novergicus) dikarenakan secara anatomis susunan saluran napas bronkus pada hewan coba ini memiliki banyak persamaan dengan manusia. Sehingga diharapkan dapat mengetahui besarnya peranan suplemen SOD-gliadin dalam menurunkan hiperplasia sel goblet saluran napas bronkus (Alexandru, 2011).

\section{METODE PENELITIAN}

Penelitian ini merupakan penelitian RCT dengan rancang bangun post test control group design pada tikus jantan galur wistar (Rattus novergicus) dan telah diuji etik di Fakultas Kesehatan Masyarakat Universitas Airlangga, Surabaya (Nomor etik: 155KEPK). Hewan coba yang digunakan berjumlah 25 ekor yang dibagi dalam 5 kelompok yang terdiri dari kelompok kontrol negatif, kelompok kontrol positif dan 3 kelompok perlakuan. Dosis pemberian suplemen SOD-gliadin diperoleh dari perhitungan tabel konversi antar organisme Laurence and Bacharach sehingga didapatkan dosis perlakuan tiap kelompok sebesar 2,25 IU, 4,5 IU dan 9 IU (Eva et al, 2014)

Sampel hewan coba tikus wistar berumur 2-3 bulan dengan berat 150 200 gram dan secara makroskopis tidak ditemukan kelainan. Proses adaptasi dilakukan terlebih dahulu selama 5 hari sebelum penelitian dimulai.

Penelitian ini dilakukan selama 28 hari. Pada masing-masing kelompok diberikan 
perlakuan yang berbeda. Kelompok pertama merupakan kelompok kontrol negatif tanpa intervensi. Kelompok kedua merupakan kelompok kontrol positif dengan intervensi paparan asap rokok. Kelompok ketiga, keempat dan kelima merupakan kelompok perlakuan dengan intervensi paparan asap rokok dan dosis ektrak melon yang berbeda yaitu 2,25 IU/hari, 4,5 IU/ hari dan $9 \mathrm{IU} /$ hari.

Pengamatan histologi bronkus pada hewan coba dilakukan dengan cara pembedahan pada organ bronkus hewan coba tikus wistar.

Setelah itu, pemotongan organ bronkus dilakukan secara membujur sepanjang $1 \mathrm{~cm}$ dan dibuat preparat histologi dalam larutan BNF (Buffer Normal Formalin) dengan menggunakan metode pewarnaan PAS (Periodic Acid Schiff). Pengamatan difokuskan pada sel goblet untuk melihat adanya hiperplasia sel goblet per $100 \mu \mathrm{m}$ pada jaringan bronkus sebanyak 4 lapang pandang yang diamati dengan perbesaran 100x (imersi).

Data yang diperoleh dilakukan pengujian statistik dengan menggunakan analisis Uji Anova untuk membandingkan persentase hiperplasia sel goblet antara kelompok kontrol, kelompok paparan rokok, kelompok ekstrak melon dengan dosis 2,25 IU/hr, 4,5 IU/hr dan $9 \mathrm{IU} / \mathrm{hr}$.

\section{HASIL}

Hasil pengamatan dilakukan dengan membandingkan persentase hiperplasia sel goblet pada masing-masing hewan coba pada tabel 1. Kadar MDA pada tikus kontrol negatif (I); tikus kontrol positif dengan paparan asap rokok (II); tikus perlakuan dengan paparan asap rokok dan dosis SODgliadin masing-masing 2,25 IU, 4,5 IU, dan 9IU Tabel 1

Pada hasil penelitian dapat dilihat pada kelompok kontrol positif terjadi peningkatan hiperplasia sel goblet dibanding kelompok negatif, sedangkan pada kelompok perlakuan
Tabel 1. Nilai rata-rata hiperplasia sel goblet tiap kelompok

\begin{tabular}{|c|c|c|c|}
\hline & Kelompok & $\begin{array}{c}\text { Rerata } \pm \\
\text { SD }\end{array}$ & $P$ value \\
\hline I & $\begin{array}{l}\text { kelompok kontrol } \\
\text { negatif tanpa } \\
\text { intervensi dan } \\
\text { paparan asap } \\
\text { rokok }\end{array}$ & $5,32 \pm 2,51$ & \\
\hline II & $\begin{array}{l}\text { kelompok kontrol } \\
\text { positif (mendapat } \\
\text { paparan asap } \\
\text { rokok) }\end{array}$ & $5,94 \pm 2,15$ & \\
\hline III & $\begin{array}{l}\text { kelompok } \\
\text { perlakuan dengan } \\
\text { paparan asap rokok } \\
\text { dan intervensi } \\
\text { dosis ektrak melon } \\
2,25 \mathrm{IU} / \text { hari }\end{array}$ & $4,74 \pm 1,62$ & 0,005 \\
\hline IV & $\begin{array}{l}\text { kelompok } \\
\text { perlakuan dengan } \\
\text { paparan asap rokok } \\
\text { dan intervensi } \\
\text { dosis ektrak melon } \\
\text { 4,5 IU/ hari }\end{array}$ & $7,18 \pm 2,05$ & \\
\hline $\mathrm{V}$ & $\begin{array}{l}\text { kelompok } \\
\text { perlakuan dengan } \\
\text { paparan asap rokok } \\
\text { dan intervensi } \\
\text { dosis ektrak melon } \\
9 \text { IU/hari }\end{array}$ & $6,18 \pm 1,42$ & \\
\hline
\end{tabular}

Keterangan: jika $\mathrm{P}<0,05$,maka $\mathrm{H} 0$ ditolak atau ada perbedaan pada masingmasing kelompok

dengan pemberian SOD-gliadin terjadi peningkatan dan penurunan yang tidak beraturan antara kelompok. Nilai hiperplasia tertinggi diperoleh pada kelompok perlakuan dengan pemberian dosis SOD-gliadin 4,5 IU/ hari sedangkan nilai terendah dari hiperplasia sel goblet diperoleh pada kelompok perlakuan dengan pemberian dosis SOD-gliadin 2,25 IU/hari.

Hasil analisis ANOVA pada hiperplasia sel goblet menunjukkan belum adanya perbedaan persentase hiperplasia sel goblet pada masing-masing kelompok $(\mathrm{p}=0.396)$. 


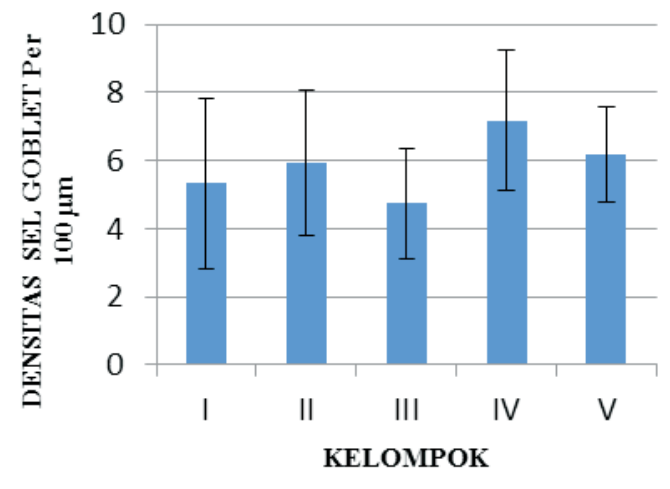

Gambar 1. Persentase Hiperplasia Sel Goblet pada tiap kelompok

Keterangan :

a) Kelompok $\mathrm{I}=$ Kelompok kontrol, merupakan kelompok tanpa paparan asap rokok dan pemberian Ekstrak Cucumis melo

b) Kelompok II = Kelompok perlakuan dengan paparan asap rokok, namun tanpa pemberian Ekstrak Cucumis melo per oral.

c) Kelompok III $=$ Kelompok perlakuan dengan paparan asap rokok dan pemberian Ekstrak Cucumis melo per oral dengan dosis 2,25 IU/ hari/ekor.

d) Kelompok IV = Kelompok perlakuan dengan paparan asap rokok dan pemberian Ekstrak Cucumis melo per oral dengan dosis 4,5 IU/hari/ekor.

e) Kelompok $\mathrm{V}=$ Kelompok perlakuan dengan paparan asap rokok dan pemberian Ekstrak Cucumis melo per oral dengan dosis 9 IU/hari/ekor

\section{PEMBAHASAN}

Hasil penelitian ini bertujuan untuk mengetahui seberapa besar peranan antioksidan superoxide dismutase terhadap hiperplasia sel goblet yang dihasilkan oleh paparan asap rokok. Pada hasil penelitian ini telah menunjukkan terjadinya perubahan struktur sel goblet, namun tidak memiliki perbedaan yang signifikan pada persentase hiperplasia sel goblet tiap kelompok perlakuan dengan pemberian ekstrak Cucumis melo dibandingkan dengan kelompok kontrol negatif (Kelompok I) dan kontrol positif (Kelompok II) $(\mathrm{p}<0,05)$.

Pada penelitian ini menunjukkan jumlah sel goblet pada kelompok I memiliki nilai rerata yang lebih kecil dari kelompok II dan tidak memiliki perbedaan yang signifikan. Hasil penelitian ini bertentangan dengan penelitian sebelumnya yang menyatakan pemberian paparan asap rokok dapat menyebabkan terjadinya hiperplasia sel goblet (Silva And Bercik, 2012).

Nilai rerata paling rendah didapat pada kelompok dengan pemberian superoxide dismutase ekstrak Cucumis melo dosis 2,25 IU/hari, sedangkan nilai rerata tertinggi didapat pada kelompok dengan pemberian superoxide dismutase ekstrak Cucumis melo dosis 4,5 IU/hari. Hasil ini menunjukkan bahwa peranan antioksidan berupa ekstrak Cucumis melo belum memberikan hasil yang signifikan terhadap penurunan hiperplasia sel goblet pada saluran napas bronkus. Namun, penelitian ini sejalan dengan penelitian sebelumnya yang menyatakan belum adanya perbedaan dalam pemberian antioksidan terhadap penurunan hiperplasia sel goblet akibat paparan asap rokok (Ramos et al., 2014).

Menurut Kim et al (2015), pengukuran hiperplasia sel goblet dapat dilakukan dengan 2 cara yaitu Goblet Cell Density (GCD) dan Mucin Volume Density (MVD). Pengukuran Goblet Cell Density (GCD) untuk menilai jumlah sel goblet yang ada pada saluran napas sedangkan Mucin Volume Density (MVD) digunakan untuk menilai banyaknya mukus yang dihasilkan per satuan luas. Perubahan Goblet Cell Density (GCD) membutuhkan waktu yang lebih lama dibandingkan dengan Mucin Volume Density (MVD).

Hal ini disebabkan dalam Goblet Cell Density (GCD) terjadi perubahan struktur sel goblet pada saluran napas sedangkan Mucin Volume Density (MVD) merupakan peningkatan jumlah mukus dalam merespons paparan asap rokok. Pada penelitian yang 
dilakukan oleh Simet et al. (2010) dan Schamberger et al. (2015) perubahan struktur hiperplasia sel goblet baru terjadi setelah lebih dari 1 bulan pemberian paparan asap rokok.

Penelitian ini menunjukkan bahwa persentase hiperplasia sel goblet belum menjadi signifikan dikarenakan perubahan struktur sel (Goblet Cell Density) membutuhkan waktu yang lebih lama dibandingkan peningkatan sekresi mukus (Mucin Volume Density) sehingga membutuhkan waktu perlakuan yang lebih panjang. Peranan antioksidan Cucumis melo dalam menurunkan hiperplasia sel goblet yang diperoleh melalui paparan asap rokok belum menunjukkan hasil yang signifikan dibandingkan tanpa pemberian antioksidan Cucumis melo.

\section{SIMPULAN}

Pengukuran hiperplasia sel goblet dapat dilakukan dengan 2 macam cara, yaitu dengan Goblet Cell Density (GCD) dan Mucin Volume Density (MVD). Namun perubahan sel goblet pada saluran napas bronkus (GCD) membutuhkan waktu yang lebih lama dibandingkan peningkatan sekresi mucus (MVD). Hal ini dikarenakan pada Goblet Cell Density telah memberikan perubahan pada struktur sel goblet di saluran napas sedangkan pada Mucin Volume Density (MVD) hanya merupakan peningkatan jumlah mucus akibat respon dari paparan asap rokok, sehingga perubahan sel goblet pada saluran napas bronkus diperkirakan belum mengalami perubahan yang signifikan.

Pada penelitian ini dapat disimpulkan bahwa pemberian antioksidan SOD dari ekstrak Cucumis melo belum memberikan pengaruh pada hyperplasia sel goblet pada saluran napas bronkus akibat paparan asap rokok.

Penelitian lanjutan mengenai efektivitas SOD dari ekstrak Cucumis melo terhadap hiperplasia sel goblet dapat dikembangkan dan disarankan untuk memberikan jumlah sampel yang lebih besar dan waktu perlakuan yang lebih lama sehingga dapat menunjukkan perubahan hiperplasia sel goblet pada saluran napas bronkus akibat paparan asap rokok.

\section{DAFTAR PUSTAKA}

Alexandru I. 2011. Experimental use of animal in research spa. Balneo research journal. $2: 1$.

Allen T.C. 2010. Pathology of small Airway. Arch Pathol Lab Med. 134 : 702-718

Angelis N., Porpodis K., Zarogoulidis P., Spyratos D., Kioumis I., Papaiwannou A., Pitsiou G., Tsakiridis K., Mpakas A., Arikas S., Tsiouda T., Katsikogiannis N., Kougioumtzi I., Machairiotis N., Argyriou M., Kessisis G., and Zarogoulidis K. (2014). Airway Inflammation in Chronic Obstructive Pulmonary Disease. Journal of Thoracic Disease. 6 (1) : S167 S172.

Augusto O. and Miyamoto S. 2011. Oxygen Radicals and Related Species. Nova Science Publishers. 1 : 11-12.

Boucherat O., Boczkowski J., Jeannotte L., and Delacourt C. 2013. Cellular and molecular mechanisms of goblet cell metaplasia in the respiratory airways. Experimental Lung Research. 39 : 4-5.

Direktorat Jenderal PP \& PL. 2011. Pedoman kawasan Tanpa Rokok. Jakarta.

Eva A., Saepudin, and Soesy A.S. 2014. Pengaruh maserat lidah buaya (aloe vera) terhadap kadar kolesterol darah mencit (mus musculus) jantan hiperglikemia. Formica. 1 (1).

Filiz E. and Tombuloglu H. 2015. Genomewide distribution of superoxide dismutase (SOD) gene families in Sorghum bicolor. Turkish journal of Biology. 39 : 49-59.

Gutowski M. and Kowalczyk S., (2013). A study of free radical chemistry: their role and pathophysiological significance. Neurovascular Research Laboratory, Faculty of Health, Science and Sport, University of Glamorgan, UK and Department of Microbiology, Faculty of Pharmacy, Poznan University of Medical 
Sciences, Poznań, Poland. Vol. 60, No 1/2013 1-16.

Hayashi T. (2012). Molecular Mechanisms of Metaplasia, Differentiation and Hyperplasia of Goblet Cellin Allergic Asthma. Allergy and Therapy Journal. $3: 3$.

Http//www.who/int/tobacco/surveillance

Kahnamoei R., Maleki F., and Nasirzadeh M.R. (2014). The effects of cigarette smoking on plasma mda and tac in university students. Indian Journal of Fundamental and Applied Life Sciences. Vol. 4 (3) July-September, pp.329-333

Kementrian Kesehatan RI. 2014. Laporan Hasil Riset Kesehatan Dasar. Jakarta. Balitbangkes Kemenkes.

Kim V., Oros M., Durra H., Kelsen S., Aksoy M., Cornwell W.D., Rogers T.J, and Criner G.J. (2015). Chronic Bronchitis and Current Smoking Are Associated with More Goblet Cells in Moderate to Severe COPD and Smokers without Airflow Obstruction.PLoS One. 10(2) : e0116108.

Nivedhini V., Chandran R. and Parimelazhagan T. (2014). Chemical composition and antioxidant activity of Cucumis dipsaceus Ehrenb. Ex Spach fruit. International Food Research Journal 21(4): 1465-1472.

Romao S. (2015). Therapeutic value of oral supplementation with melon superoxide dismutase and wheat gliadin combination. Nutrition, j. Nutrition. $31: 430-436$. doi: 10.1016/j.nut.2014.10.006. Epub 2014 Nov 5

Russi E.W., Karrer W., Brutsche M., Eich C., Fitting J.W., Frey M., Geiser T., Kuhn M.,Nicod L., Quadri F., Rochat T., Steurer-Stey C., and Stolz D. (2013).
Diagnosis and Management of Chronic Obstructive Pulmonary Disease: The Swiss Guidelines. Respiration. 85 : 160 -174 .

Schamberger A.C., Staab-Weijnitz C.A., Mise-Racek N. and Eickelberg O. (2015). Cigarette smoke alters primary human bronchial epithelial cell differentiation at the air-liquid interface. Scientific Reports. $5: 8163$

Silva M. And Bercik P. (2012). Blood, Lymphatics, Immune System and Stem Cells. Macrophages are related to goblet cell hyperplasia and induce MUC5B but not MUC5AC in human bronchus epithelial cells. Laboratory Investigation. $92: 937-948$.

Simet S.M., Sisson J.H., Pavlik J.A., DeVasure J.M., Boyer C., Liu X, Kawasaki S, Sharp J.G., Rennard S.I., and Wyatt T.A. (2010). Long-Term Cigarette Smoke Exposure in a Mouse Model of Ciliated Epithelial Cell Function. Am J Respir Cell Mol Biol. 43(6): 635-640.

Sisein E.A. (2014). Biochemistry of Free Radicals and Antioxidants. Scholars Academic Journal of Biosciences (SAJB). 2(2): 110-118.

Vlahos R. and Bozinovski S. (2014). Recent advances in pre-clinical mouse models of COPD. Clinical Science. 126 (4) : $253-265$.

Vouldoukis I., Conti M., Krauss P, Kamate C, Blazquez S , Tefit M., Mazier D. , Calenda A. and Dugas B. (2014). Supplementation with Gliadin-combined Plant Superoxide Dismutase Extract Promotes Antioxidant Defences and Protects Against Oxidative Stress. Phytotherapy Research. 18 : 957 -962 . 